\title{
CONTRACTOR SELECTION FOR CONSTRUCTION WORKS BY APPLYING SAW-G AND TOPSIS GREY TECHNIQUES
}

\author{
Edmundas Kazimieras Zavadskas ${ }^{1}$, Tatjana Vilutiene ${ }^{2}$, \\ Zenonas Turskis ${ }^{3}$, Jolanta Tamosaitiene ${ }^{4}$ \\ Vilnius Gediminas Technical University, Civil Engineering Faculty, \\ Dept of Construction Technology and Management, Sauletekio al. 11, \\ LT-2040 Vilnius, Lithuania. \\ E-mails:.1edmundas.zavadskas@vgtu.lt; ${ }^{2}$ tatjana.vilutiene@vgtu.lt; \\ 3zenonas.turskis@vgtu.lt; ${ }^{4}$ jolanta.tamosaitiene@vgtu.lt
}

Received 5 March 2009; accepted 20 February 2010

\begin{abstract}
The accuracy of performance measures in common multicriteria methods is usually assumed to be accurate. Grey theory is a new technique for performing prediction, relational analysis and decision-making in many areas. This paper presents applicability of grey theory techniques for defining the utility of an alternative. Proposed assessment model covers well known method of TOPSIS (Technique for Order Preference by Similarity to Ideal Solution), method with attributes values determined at intervals (TOPSIS-grey) and a new method of Simple Additive Weighting with Grey relations (SAW-G). A case study of the assessment of contractors' competitive ability was used to demonstrate the applicability and the effectiveness of the proposed approach. The results show that the methods of grey relations methodology can be implemented as an effective decision aid for tasks with uncertain data.
\end{abstract}

Keywords: contractors, construction, multicriteria, decision-making, grey numbers, SAW, SAW-G, TOPSIS, TOPSIS grey.

Reference to this paper should be made as follows: Zavadskas, E. K.; Vilutiene, T.; Turskis, Z.; Tamosaitiene, J. 2010. Contractor selection for construction works by applying SAW-G and TOPSIS Grey techniques, Journal of Business Economics and Management 11(1): 34-55.

\section{Introduction}

The progress of a national economy and society is impossible without the construction, because the result of construction - real estate of various purposes - is necessary for people to live, to work and to satisfy their social and other needs. Globally, the construction sector contributes one tenth to the total (annual) production of goods and services on average (Urbanavičienè et al. 2009). The construction products are very expensive, buildings and structures make the biggest share of assets both at the level of households, companies and the entire country. Therefore, negotiations on contract provisions (construction, services, management, maintenance, etc.) and on real estate sales must be efficient (Urbanavičienè et al. 2009). An increasing number of studies 
have identified the importance of management in construction projects. With a focus on different aspects of management, various sets of critical success factors have been suggested in the literature (Yang et al. 2009a). Decision-making or "problem solving", as a broader term, is the process of selecting one or a few alternatives that should be the most favourable. In this respect, the choice of construction contractor can be handled as a multiple-criteria decision-making problem. In order to reach an optimum decision, well-defined criteria and superb solution techniques are required (Ulubeyli and Kazaz 2009). It is important to evaluate the environmental impact and to integrate sustainability concepts into decision-making. A simple distinction should be drawn between "external" sustainability assessments that may be conducted by regulators as part of a project approval process, and "internal" sustainability assessment conducted by companies themselves as part of their business planning and decision-making processes (Stasiškienè and Šliogerienè 2009).

Many researchers emphasize the importance of rational decision-making in constantly changing environment. In an intricate and dynamic market, decision making is a complex human cognitive process with regard to uncertainties such as price and interest volatility. Therefore, institutional investors and practitioners are always immersed in managing their investment portfolios, not only to optimize returns, but more importantly to minimize potential risks (Hui et al. 2009).

Construction industry, though quite specific, obeys the same laws of economy as other sectors. Construction companies encounter the risks, like many others, operate in the market and can go bankrupt (Kapliński 2008). To find and accept the right decision in construction industry is a difficult problem. Decision-maker usually has too little information and it is usually incomplete. The rational mean for the decision-making is application of the multi-criteria decision-making (MCDM) techniques and their modifications.

\section{The problem of the contractor selection}

Selection of the right contractor is a very important task in construction. Choosing the proper contractor from numerous applicants that are available today in market is a complicated problem for clients. In dealing with the long-term assets, it is crucial to select a proper contractor, which could ensure the quality of the constructed building. The achievement of this aim largely depends on the efficiency of the performance of the contractor that is selected.

Contractor prequalification makes it possible to admit for tendering only competent contractors. The undertaken decisions demand taking into consideration many criteria, including among others, experience and financial standing of the candidates that are often difficult to be quantified (Plebankiewicz 2009). Long-term, performance-based contracting offers many advantages compared to the competitive tendering approach (Straub 2009). One of the main benefits is that long-term performance-based contracting reduces both direct and indirect costs. The modelling of multicriteria selection is getting more and more important (Jakimavičius and Burinskienè 2009) because of the increasing rate of competitiveness in business. To plan, control and organize contrac- 
tor selection in the most efficient way, it is needed to consider the different aspects of business environment and all life cycle of a building. The multi-alternative design and multiple criteria analysis of the life cycle of a building is described by Banaitiene et al. (2008); management control systems and stakeholders' interests in multinational companies industry are presented by Jurkštienè et al. (2008).

On one side, contractor selection process has influence on the general situation in Lithuanian economy (Tvaronavičienè and Grybaite 2007). On the other side, claims are influenced by the external environment (Mitkus and Šostak 2008). Contractor choice influences the project success. In the primary stage it is necessary to perform the strategic planning and management (Karnitis and Kucinskis 2009). Schieg (2008) analysed strategies for avoiding asymmetric information in construction project management and proposed the model for integrated project management (Schieg 2009). Zavadskas et al. (2008c) offered a new approach to determining the retrofit effectiveness of houses based both on expected energy savings and the increase in market value of renovated buildings. Reichelt et al. (2008) suggested the theoretical model for rational maintenance strategy selection with an emphasis on rapidly changing environmental conditions for the proper maintenance of buildings. In internal environment, main influences have the selection of the right project manager for construction project. Contractors' project managers' characteristics are considered to be less important (Zavadskas et al. 2008e).

Many authors analysed the problem of contractor selection in the following fields:

- Arslan et al. (2008) presented sub-contractor selection process in construction projects: Web-based sub-contractor evaluation system (WEBSES);

- Bayraktar and Hastak (2009) proposed a decision support system for selecting the optimal contracting strategy projects;

- Chan and Au (2009) stated that the main step is establishing the criteria influencing assessment of the contractors' for construction works assets;

- Hartmann et al. (2009) analysed relative importance of contractor selection criteria;

- Enshassi et al. (2009) analysed contractors' perception towards causes of claims in construction projects;

- Walraven and de Vries (2009) analysed contractor selection from demand-driven towards value-driven contractor selection;

- Padhi and Mohapatra (2009) proposed centralized construction contractor selection considering past performance of contractors;

- Darvish et al. (2009) presented application of the graph theory and matrix methods to contractor ranking;

- Lam et al. (2009) proposed the model for contractor prequalification;

- Mitkus and Trinkūnienè (2008) analysed connection of the contractors with subcontractors and suppliers;

- Padhi and Mohapatra (2009) investigated contractors' selection problem in government procurement auctions;

- Smyth and Fitch (2009) presented contractor application of relationship marketing and management; 
- Šiškina et al. (2009) investigated evaluation problem of the competitiveness of construction company overhead costs.

- Bageis and Fortune (2009) had analysed the factors affecting the bidding decision in construction.

All construction process is risky. Contractual risk management forms only one part of the companies' legal risk management and, in this way, it is part of companies' comprehensive general risk management. The goals of contractual risk management do not restrict the management of legal risks in contracting. Contractual risk management also covers other risks in business by using methods of contractual planning and management (Tieva and Junnonen 2009). Risk management in construction is a tedious task as the objective functions tend to change during the project life cycle (Dikmen et al. 2008). Risk management process in construction is analysed and the importance of it was emphasized by many authors (Han et al. 2008; Shevchenko et al. 2008; Suhobokov 2008; Zavadskas et al. 2008d; El-Adaway and Kandil 2009; Huang 2009; Zavadskas and Vaidogas, 2008).

To understand and manage risks in construction projects, the construction process can be divided into four phases, which describe the primary and implementation stages of construction project (Fig. 1):

- design phase,

- bidding phase,

- construction phase,

- completion phase.

The model of project implementation at primary stage and elaboration of contractor selection in bidding phase during primary stage of project implementation is shown in Fig. 2.

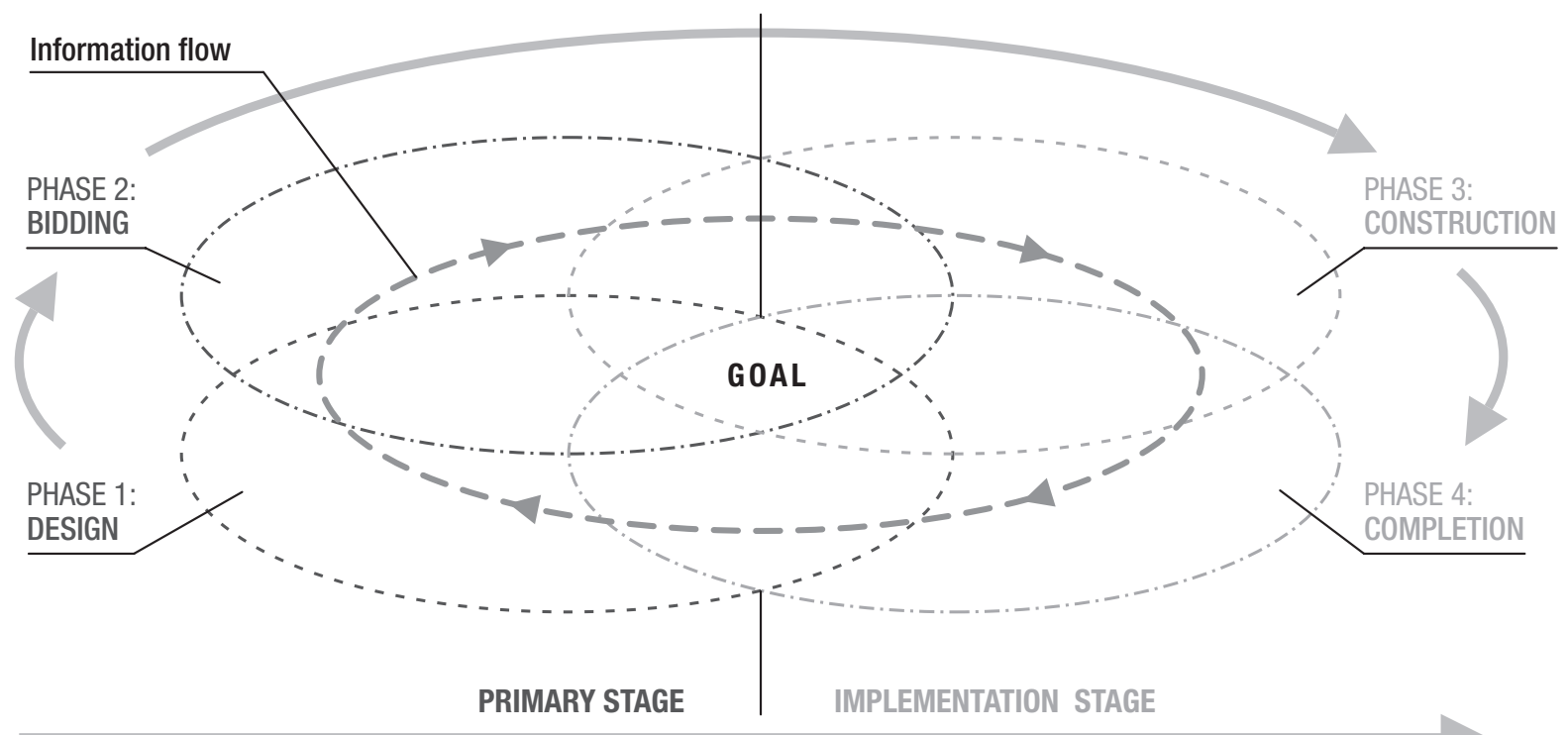

Fig. 1. The information flow between interacting stages in construction 


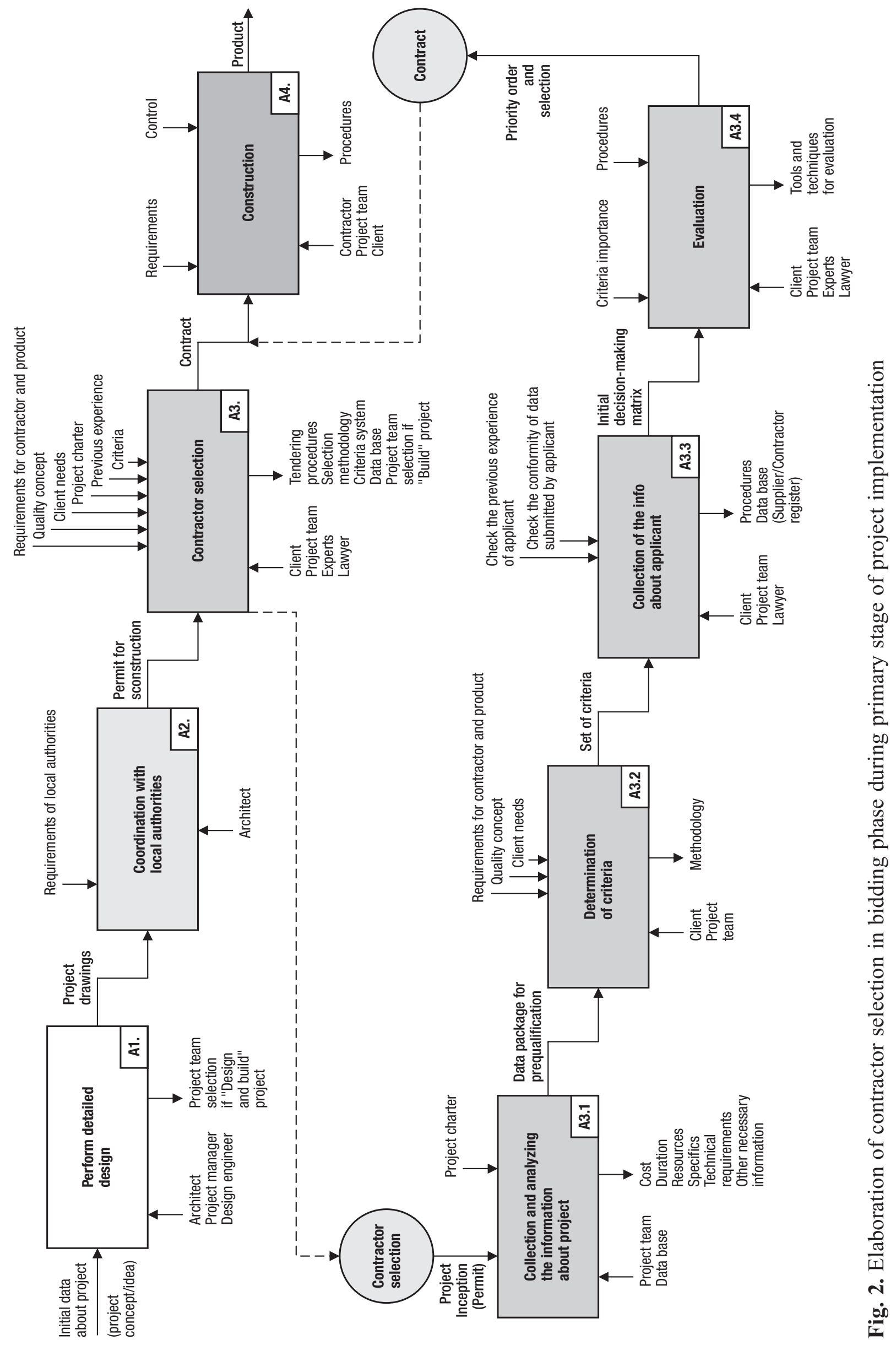




\section{Combining MCDM methods with Grey theory system}

Multiple criteria decision aid provides several powerful solution tools for confronting sorting problems (Hwang and Yoon 1981; Figueira et al. 2005; Zavadskas and Kaklauskas 2007; Ginevičius et al. 2008a, b; Liaudanskiene et al. 2009; Zavadskas et al. 2008b). There can be used very simplified techniques for the evaluation such as SAW - Simple Additive Weighting (MacCrimon 1968); TOPSIS - Technique for Order Preference by Similarity to Ideal Solution (Hwang and Yoon 1981).

When we consider a discrete set of alternatives described by some criteria, there are three different types of analysis that can be performed in order to provide significant support to decision-makers:

- Ensure that the decision-maker follows a ,rational“ behaviour (normative option) Value functions, Utility theory, distance to the Ideal;

- Give some advice based on reasonable (but not indisputable) rules;

- Find the preferred solution from the partial decision hypothesis - interactive methods.

The analysis of the purpose is to be achieved by using criteria of effectiveness, which have different dimensions, different significances as well as different directions of optimization (Kendall 1970; Ehrgott 2005). The discrete criteria values can be normalized by applying different normalization methods (Zavadskas and Turskis 2008). The purpose of analysis can also be different (Bregar et al. 2008). Multiple criteria decision aid analysed by Hwang and Yoon (1981) provides several powerful and effective tools for confronting sorting problems analysed by Figueira et al. (2005).

There is a wide range of methods based on multi-criteria utility theory: SAW (MacCrimon 1968; Ginevičius et al. 2008a, b); MOORA - Multi-Objective Optimization on basis of Ratio Analysis (Brauers et al. 2008a, 2008b; Kalibatas and Turskis 2008); TOPSIS (Hwang and Yoon 1981); VIKOR - compromise ranking method (Opricovic 1998; Opricovic and Tzeng 2004); COPRAS (Zavadskas et al. 2008a, 2009); and other methods (Turskis 2008; Turskis et al. 2009).

Decision-makers in their activities deal with uncertain future. The multicriteria decisionmaking could be applied to assess different alternatives of future activities. Hui et al. (2009) incorporated the fuzzy concept in linear programming to obtain the best possible outcome in portfolios, when direct real estate investment is included.

The best strategy could be selected from available scenarios, and information. In strategic decisions, dealing with uncertainty, the values of criteria could be determined at intervals - from pessimistic value to optimistic value.

The limits of criterion value could also be determined by expert. In this case determination of limits depends on the qualification and experience of expert. Therefore it is better to collect the objective data.

Deng (1982) developed the Grey system theory and described operations with grey numbers. Grey relational analysis possesses advantages ( Deng 1988, 1989), i.e.:

- involves simple calculations,

- requires smaller samples, 
- a typical distribution of samples is not needed,

- the quantified outcomes from the Grey relational grade do not result in contradictory conclusions to qualitative analysis,

- the Grey relational grade model is a transfer functional model that is effective in dealing with discrete data.

Lin et al. (2004) analysed the state-of-the-art of the theory and applications of the socalled grey systems theory founded in the 1980s. Li and Liu (2009a) had performed the input-occupancy-output analysis and proposed grey model of input-occupancy-output analysis for grey situations and for managing the economic systems with missing information. They also explained the connotation of grey number, which is the basic unit of grey mathematics and the key to establish the mathematical framework of grey system theory (Li and Liu 2009b). Li et al. (2009) developed Grey-Markov chain algorithm. They found that combining the grey model, Markov chains, and least square method, can be a new algorithm for forecasting the tendency of the gross amount of energy sources consumption. Cakir (2008) developed the grey extent analysis and had shown that the proposed procedure can be used as a decision-making tool where the judgments of the decision-maker are not exact (i.e. in terms of grey system terminology they are not "white"). Kuo et al. (2008) analysed the use of grey relational analysis in solving multiple criteria decision-making problems. Du and Sheen (2005) developed the pavement permanent deformation prediction model by grey modeling method. Lin and Lee (2007) presented a novel high-precision grey forecasting model.

Liu and Lin (2006) have specified free possibilities for occurrence of the White, Grey and Black information (Table 1).

Grey theory was applied:

- to thermal point optimization (Yan and Yang 2009),

- to automatic stock market forecasting and portfolio selection (Huang 2009),

- to emergence and development of grey system theory (Liu et al. 2009),

Table 1. Comparison of White, Grey and Black systems (Liu and Lin 2006)

\begin{tabular}{cccc}
\hline & \multicolumn{3}{c}{ Systems } \\
\hline White & Grey & Black \\
\hline Information & Known & Incomplete & Unknown \\
\hline Appearance & Bright & Grey & Dark \\
\hline Process & Old & Replace old with new & New \\
\hline Property & Order & Complexity & Chaos \\
\hline Methodology & Positive & Transition & Negative \\
\hline Attitude & Seriousness & Tolerance & Indulgence \\
\hline Conclusion & Unique solution & Multiple solution & No results \\
\hline
\end{tabular}


- to a hybrid model for stock market forecasting and portfolio selection based on ARX, grey system and RS theories (Huang and Jane 2009),

- to grey forecasting in vibration condition monitoring of machines (Cempel 2008),

- to supplier selection by a grey-based rough decision-making approach (Li et al. 2008),

- to grey prediction on indoor comfort temperature for HVAC systems (Leephakpreeda 2008),

- to building thermal process analysis (Wending et al. 2002).

\section{Methodology and application}

This paper presents the application of newly developed TOPSIS grey, SAW-G methods for the case study of contractor selection.

The TOPSIS method was developed by Hwang and Yoon (1981). TOPSIS method belongs to MCDM (Multi-criteria decision-making method) group and identifies solutions from a finite set of alternatives based upon simultaneous minimization of distance from an ideal point and maximization of distance from a negative ideal point. TOPSIS can incorporate relative weights of criteria. The only subjective input needed is weights. Lin et al. (2008) developed TOPSIS method with grey number operations to the problem solution with uncertain information. A new decision support system for performance measurement using combined fuzzy TOPSIS/DEA approach was presented by Zeydan and Colpan (2009).

TOPSIS method was applied in many fields:

- to selection of the strategic alliance partner (Buyukozkan et al. 2008),

- for supplier selection with TOPSIS method (Boran et al. 2009),

- to risk evaluation in workplaces (Grassi et al. 2009),

- to customer evaluation using fuzzy methods based on TOPSIS (Chamodrakas et al. 2009),

- in safety management (Yang et al. 2009b).

The general algorithm of problem solution, applying SAW-G and TOPSIS grey method is presented in Fig. 3.

MacCrimon (1968) developed SAW method and it was applied for multicriteria decision-making in various fields:

- for a simulation and comparison of selected methods (Zanakis et al. 1998),

- for solving fuzzy MADM problems (Hui et al. 2009),

- for facility location selection with objective/subjective criteria by applying a fuzzy simple additive weighting system under group decision-making (Chou et al. 2008),

- e-commerce performance assessment model in the retail sector of China (Huang et al. 2009),

- for contractors ranking (Darvish et al. 2009),

- for evaluation of transportation zones in Vilnius City, analysis and ranking (Jakimavicius and Burinskiene 2009b). 


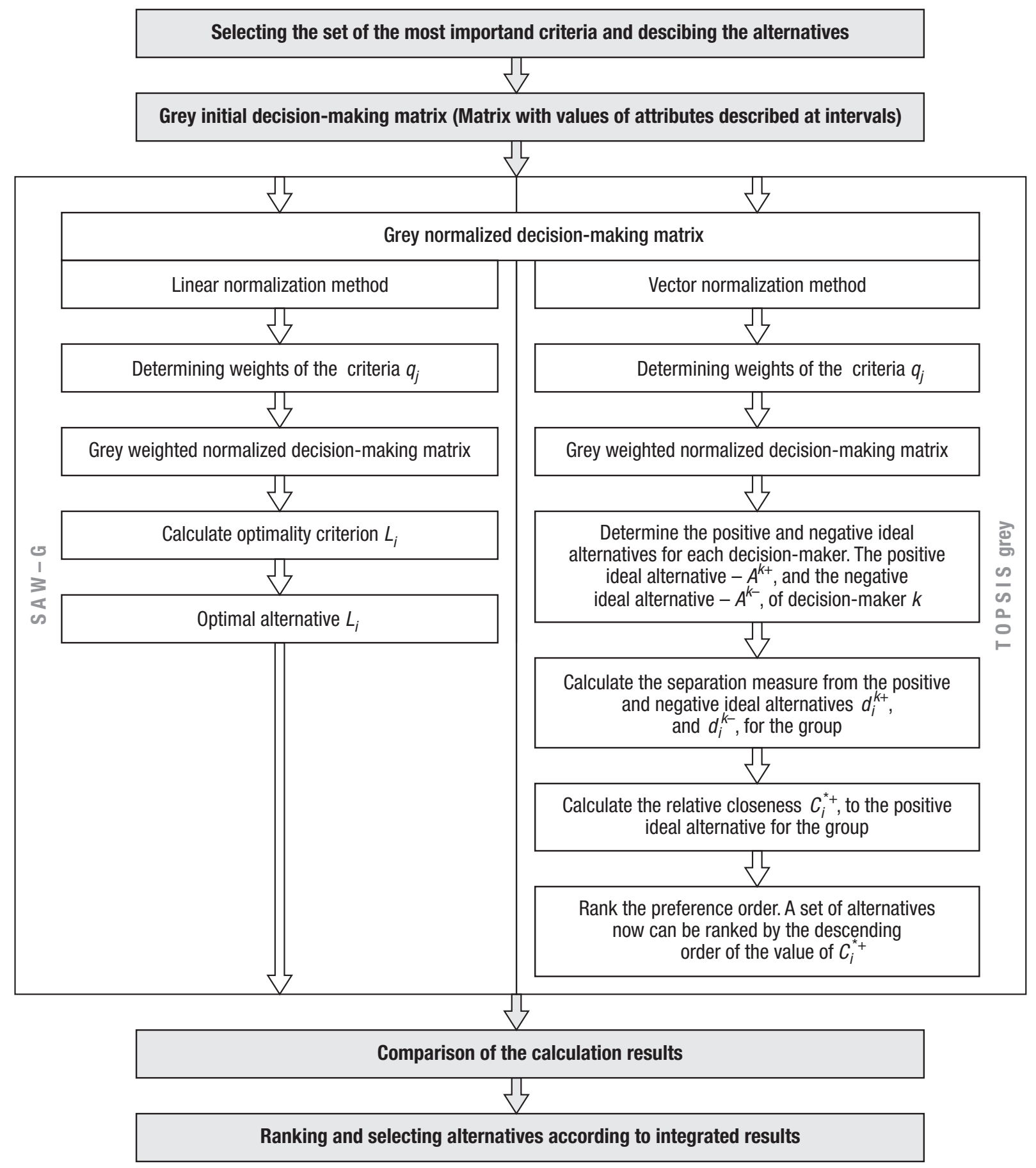

Fig. 3. The main algorithm of problem solution applying SAW-G and TOPSIS grey method

\subsection{Newly developed technique - SAW-G method}

The Simple Additive Weighting method with grey number can be described as stepwise procedure:

Step 1: Selecting the set of the most important criteria, describing the alternatives;

Step 2: Constructing the decision-making matrix $\otimes X$.

Step 3: Normalization procedure for obtaining comparable scales. The normalized values are calculated as follows: 


$$
\begin{gathered}
\bar{w}_{i j}=\frac{w_{i j}}{\max _{j} w_{i j}} ; \bar{b}_{i j}=\frac{b_{i j}}{\max _{j} w_{i j}} ; \\
\bar{w}_{i j}=\frac{\min _{j} b_{i j}}{w_{i j}} ; \bar{b}_{i j}=\frac{\min _{j} b_{i j}}{b_{i j}} .
\end{gathered}
$$

If $\min x_{i j}$ is preferable

$$
\otimes X=\left[\begin{array}{cccc}
{\left[\bar{w}_{11} ; \bar{b}_{11}\right]} & {\left[\bar{w}_{12} ; \bar{b}_{12}\right]} & \ldots & {\left[\bar{w}_{1 m} ; \bar{b}_{1 m}\right]} \\
{\left[\bar{w}_{21} ; \bar{b}_{21}\right]} & {\left[\bar{w}_{22} ; \bar{b}_{22}\right]} & \ldots & {\left[\bar{w}_{2 m} ; \bar{b}_{2 m}\right]} \\
\vdots & \ddots & \vdots \\
{\left[\bar{w}_{n 1} ; \bar{b}_{n 1}\right]} & {\left[\bar{w}_{n 2} ; \bar{b}_{n 2}\right]} & \ldots & {\left[\bar{w}_{n m} ; \bar{b}_{n m}\right]}
\end{array}\right] .
$$

Step 4: Determining weights of the criteria $q_{j}$.

Step 5: Weighted - normalized decision-making matrix is obtained according to equation (4):

$$
\otimes \hat{x}_{i j}=\otimes \bar{x}_{i j} \cdot q_{j} ; \hat{w}_{i j}=\bar{w}_{i j} \cdot q_{j} ; \hat{b}_{i j}=\overline{b_{i j}} \cdot q_{j} .
$$

In formula (19), $q_{j}$ is the weight of the $j-$ th attribute.

Step 6: The next step is to calculate optimality criterion $L$ which is determined as maximal value of $L_{i}$ :

$$
L_{i}=\frac{1}{n} \sum_{j=1}^{m} \frac{\bar{w}_{j}+\bar{b}_{j}}{2} .
$$

Step 7: Optimal alternative is determined as maximal value of $L_{i}$.

\subsection{TOPSIS method with criteria values determined} at intervals (Lin et al. 2008)

The TOPSIS method is one of the best described mathematically and not simple for practical using. Lin et al. (2008) proposed the model of TOPSIS method with attributes values determined at intervals that includes the following steps:

Step 1: Selecting the set of the most important attributes, describing the alternatives;

Step 2: Constructing the decision-making matrix $\otimes X$. Grey number matrix $\otimes X$ can be defined as:

$$
\otimes X=\left[\begin{array}{cccc}
\otimes x_{11} & \otimes x_{12} & \ldots & \otimes x_{1 m} \\
\otimes x_{21} & \otimes x_{22} & \ldots & \otimes x_{2 m} \\
\vdots & \vdots & \ddots & \vdots \\
\otimes x_{n 1} & \otimes x_{n 2} & \ldots & \otimes x_{n m}
\end{array}\right] ; \quad i=\overline{1, n} ; \quad j=\overline{1, m}
$$


where $\otimes x_{i j}$ denotes the grey evaluations of the $i$-th alternative with respect to the $j$-th attribute; $\left[\otimes x_{i 1}, \otimes x_{i 2}, \ldots, \otimes x_{i m}\right]$ is the grey number evaluation series of the $i$-th alternative.

Step 3: Construct the normalized grey decision matrices. The normalized values of maximizing attributes are calculated as:

$$
\otimes \bar{x}_{i j, b}=\frac{\otimes x_{i j}}{\max _{i}\left(b_{i j}\right)}=\left(\frac{w_{i j}}{\max _{i}\left(b_{i j}\right)}, \frac{b_{i j}}{\max _{i}\left(b_{i j}\right)}\right) .
$$

The normalized values of minimizing attributes are calculated as (formula (4) which differs from formula used by Lin et al. (2008):

$$
\otimes \bar{x}_{i j, w}=1-\frac{\otimes x_{i j}}{\max _{i}\left(b_{i j}\right)}=\left(1-\frac{b_{i j}}{\max _{i}\left(b_{i j}\right)} ; 1-\frac{w_{i j}}{\max _{i}\left(b_{i j}\right)}\right) .
$$

Step 4: Determining weights of the criteria $q_{j}$.

Step 5: Construct the grey weighted normalized decision-making matrix.

Step 6: Determine the positive and negative ideal alternatives for each decision-maker. The positive ideal alternative $\mathrm{A}^{+}$, and the negative ideal alternative $\mathrm{A}^{-}$can be defined as:

$$
A^{+}=\left\{\left(\max _{i} b_{i j} \mid j \in J\right),\left(\min _{i} w_{i j} \mid j \in J^{\prime}\right) \mid i \in n\right\}=\left[x_{1}^{+}, x_{2}^{+}, \ldots, x_{m}^{+}\right]
$$

and

$$
A^{-}=\left\{\left(\min _{i} w_{i j} \mid j \in J\right),\left(\max _{i} b_{i j} \mid j \in J^{\prime}\right) \mid i \in n\right\}=\left[x_{1}^{-}, x_{2}^{-}, \ldots, x_{m}^{-}\right] .
$$

Step 7: Calculate the separation measure from the positive and negative ideal alternatives, $d_{i}^{+}$and $d_{i}^{-}$, for the group. There are two sub-steps to be considered: the first one concerns the separation measure for individuals; the second one aggregates their measures for the group.

Calculate the measures from the positive and negative ideal alternatives individually. For decision-maker $\mathrm{k}$, the separation measures from the positive ideal alternative $d_{i}^{+}$ and negative ideal alternative $d_{i}^{-}$are computed through weighted grey number as:

$$
\begin{aligned}
& d_{i}^{+}=\left\{\frac{1}{2} \sum_{j=1}^{m} q_{j}\left[\left|x_{j}^{+}-\bar{w}_{i j}\right|^{p}+\left|x_{j}^{+}-\bar{b}_{i j}\right|^{p}\right]\right\}^{1 / p} ; \\
& d_{i}^{-}=\left\{\frac{1}{2} \sum_{j=1}^{m} q_{j}\left[\left|x_{j}^{-}-\bar{w}_{i j}\right|^{p}+\left|x_{j}^{-}-\bar{b}_{i j}\right|^{p}\right]\right\}^{1 / p} .
\end{aligned}
$$


In equations (11) and (12), for $\mathrm{p} \geq 1$ and integer, $q_{j}$ is the weight for the attribute $j$, which can be determined by attribute weight determination methods. If $p=2$, then the metric is a weighted grey number Euclidean distance function. Equations (11) and (12) will be as follows:

$$
\begin{aligned}
& d_{i}^{+}=\sqrt{\frac{1}{2} \sum_{j=1}^{m} q_{j}\left[\left|x_{j}^{k+}-\bar{w}_{i j}^{k}\right|^{2}+\left|x_{j}^{k+}-\bar{b}_{i j}^{k}\right|^{2}\right]}, \\
& d_{i}^{-}=\sqrt{\frac{1}{2} \sum_{j=1}^{m} q_{j}\left[\left|x_{j}^{k-}-\bar{w}_{i j}^{k}\right|^{2}+\left|x_{j}^{k-}-\bar{b}_{i j}^{k}\right|^{2}\right]} .
\end{aligned}
$$

Step 8: Calculate the relative closeness $C_{i}^{+}$, to the positive ideal alternative for the group. The aggregation of relative closeness for the $i$-th alternative with respect to the positive ideal alternative for the group can be expressed as:

$$
C_{i}^{+}=\frac{d_{i}^{-}}{d_{i}^{+}+d_{i}^{-}} .
$$

where $0 \leq C_{i}^{+} \leq 1$. The larger the index value is, the better the evaluation of alternative will be.

Step 9: Rank the preference order. A set of alternatives now can be ranked by the descending order of the value of $C_{i}^{+}$.

\section{Case study: contractor's selection for construction of prefabricated wooden shield-shaped houses}

To illustrate the effectiveness of the MADM approach method, we have ranked the contractors for the construction works of the wooden houses.

Rising prices of multi-flat dwellings and their expensive maintenance and additional costs force more and more people in Lithuania to consider the possibility to live in an individual house instead of a flat in multi-flat dwellings. Another reason to change the living space is the appearance of new construction technologies and cheaper materials, which make housing affordable.

Recently in Lithuania in construction of individual houses the traditions of wooden construction are revitalizing. The construction of prefabricated wooden shield-shaped houses became popular due to fast construction, healthy indoor environment, less construction duration in comparison with the same houses constructed from brick or stone.

In Lithuania there are about 80 small and medium companies, which produce, construct and sell the wooden shield-shaped houses.

Great part (about 95\%) of wooden shield-shaped houses produced in Lithuania is sold abroad, mostly in Europe - Norway (30\%), Sweden (16\%), Denmark (14\%), Finland $(13 \%)$, Island (11\%), Spain $(8 \%)$, France $(6 \%)$, and others $(5 \%)$.

The survey of consumers in Lithuania shows that the most part of them will choose the wooden shield-shaped house because it is comparatively cheap $(10 \%)$, healthy $(36 \%)$ 
and construction of it is fast (34\%). $20 \%$ of respondents had showed many other reasons to choose the wooden shield-shaped house, e.g. it is well insulated (warm house), comfortable, modern, healthy. The priority was given to good insulation, comparatively low price, healthy materials and fast construction process. The model for contractor selection is presented in Fig.3. Explanation of criteria used in case study:

Experience of executives. This criterion shows the range of experience (measured in years) of executives employed directly in company production division and authorized to manage the processes.

Number of constructed houses. This criterion shows the change of annual number of constructed prefabricated wooden houses in the period of 2005-2008.

Turnover. Company turnover at the beginning and the end of the year measured in million Lt.

Number of executives. Number of executives employed in company production division in different positions.

Market share. Market share is the portion or percentage of sales of a particular product or service in a given region. In case study the distribution of shares of companies in Lithuanian market was analysed. The market share was calculated by comparing the number of prefabricated wooden houses of each company with the total of prefabricated wooden houses produced by all companies in analysed market. In initial data table the change of share for one-year period (at the beginning and the end of the year 2008) is presented.

Production method of wooden houses. Production of components for prefabricated wooden houses could be organized by different ways. Most of Lithuanian companies (58\%) use semi-automated methods for production, fully automatic production lines are used by only $2 \%$ of companies, and even $40 \%$ produce wooden components for houses manually. The level of automation in production in case study was evaluated in points: one point was given to the manual production method, two points - for semi-automated methods, and three points - for fully automated production lines. The companies analysed in case study in the beginning of their activities had used manual production.

In Table 2 the data of the following criteria are presented:

$\otimes x_{1}-$ experience of executives (years),

$\otimes x_{2}-$ number of constructed houses (units in 2005-2008, year),

$\otimes x_{3}$ - turnover (in $10^{6} €, 2005-2008$, year),

$\otimes x_{4}-$ number of executives (persons in 2005-2008, year),

$\otimes x_{5}-$ market share (portion of sales),

$\otimes x_{6}-$ production method (in point).

Optimization directions of the selected criteria are as follows:

$$
\begin{aligned}
& x_{4} \stackrel{\text { optimization direction }}{\longrightarrow} \text { min; } \\
& x_{1}, x_{2}, x_{3}, x_{5}, x_{6} \stackrel{\text { optimization direction }}{\longrightarrow} \max .
\end{aligned}
$$


Ranking of alternatives by applying SAW-G and TOPSIS grey technique is performed by applying TOPSIS method.

The initial decision-making matrix with values determined at intervals is presented in Table 2. In Table 2 given notations $q_{j}$ are the criteria weights and $A_{1}, \ldots, A_{5}$ are alternative contractors. The full names of the contractors are not provided for the sake of confidentiality.

To determine the weights of the attributes, the expert's judgment method is applied (Kendall 1970). In order to establish the weights, a survey has been carried out and 10 experts have been questioned. These experts, basing their answers on their knowledge, experience and intuition, had to rate attributes of effectiveness starting with the most important ones. The rating was done on a scale from 1 to 6 , where 6 meant "very important" and 1 "not important at all". In Table 3 the normalized decision-making matrix with value of each criteria expressed at intervals is presented. The weights of the criteria are calculated by both: SAW-G and TOPSIS grey technique. The results of the calculation for each project are presented in Table 4.

Table 2. Initial decision-making matrix with values (TOPSIS grey and SAW-G methods)

\begin{tabular}{|c|c|c|c|c|c|c|c|c|c|c|c|c|}
\hline \multirow{4}{*}{$\begin{array}{c}\text { Alternatives } \\
\text { Optimum } \\
A_{1}\end{array}$} & \multicolumn{12}{|c|}{ Criteria } \\
\hline & \multicolumn{2}{|c|}{$\otimes x_{1}$} & \multicolumn{2}{|c|}{$\otimes x_{2}$} & \multicolumn{2}{|c|}{$\otimes x_{3}$} & \multicolumn{2}{|c|}{$\otimes x_{4}$} & \multicolumn{2}{|c|}{$\otimes x_{5}$} & \multicolumn{2}{|c|}{$\otimes x_{6}$} \\
\hline & \multicolumn{2}{|c|}{$\max$} & \multicolumn{2}{|c|}{$\max$} & \multicolumn{2}{|c|}{$\max$} & \multicolumn{2}{|c|}{$\min$} & \multicolumn{2}{|c|}{$\max$} & \multicolumn{2}{|c|}{$\max$} \\
\hline & 11 & 15 & 10 & 15 & 3.30 & 4.5 & 35 & 48 & 0.152 & 0.203 & 1 & 2 \\
\hline$A_{2}$ & 10 & 14 & 7 & 13 & 2.54 & 3.68 & 40 & 58 & 0.111 & 0.162 & 1 & 2 \\
\hline$A_{3}$ & 14 & 18 & 5 & 9 & 1.95 & 2.46 & 42 & 53 & 0.079 & 0.121 & 1 & 3 \\
\hline$A_{4}$ & 12 & 16 & 1 & 4 & 0.42 & 1.73 & 15 & 63 & 0.01 & 0.054 & 1 & 2 \\
\hline$A_{5}$ & 6 & 10 & 2 & 9 & 0.62 & 2.67 & 10 & 46 & 0.012 & 0.122 & 1 & 2 \\
\hline Optimal value & \multicolumn{2}{|c|}{18} & \multicolumn{2}{|c|}{15} & \multicolumn{2}{|c|}{4.5} & \multicolumn{2}{|c|}{10} & \multicolumn{2}{|c|}{0.203} & \multicolumn{2}{|c|}{3} \\
\hline
\end{tabular}

Table 3. Normalized decision-making matrix (TOPSIS grey and SAW-G methods)

\begin{tabular}{ccccccccccccc}
\hline Alternatives & \multicolumn{10}{c}{ Normalized values of criteria } \\
\cline { 2 - 13 } & \multicolumn{2}{c}{$\otimes \bar{x}_{1}$} & \multicolumn{1}{c}{$\otimes \bar{x}_{2}$} & \multicolumn{1}{c}{$\otimes \bar{x}_{3}$} & $\otimes \bar{x}_{4}$ & $\otimes \bar{x}_{5}$ & & $\otimes \bar{x}_{6}$ \\
\cline { 2 - 13 } & $\bar{w}_{1}$ & $\bar{b}_{1}$ & $\bar{w}_{2}$ & $\bar{b}_{2}$ & $\bar{w}_{3}$ & $\bar{b}_{3}$ & $\bar{w}_{4}$ & $\bar{b}_{4}$ & $\bar{w}_{5}$ & $\bar{b}_{5}$ & $\bar{w}_{6}$ & $\bar{b}_{6}$ \\
\hline Weights $\boldsymbol{q}_{\boldsymbol{j}}$ & 0.22 & 0.22 & 0.26 & 0.26 & 0.11 & 0.11 & 0.09 & 0.09 & 0.15 & 0.15 & 0.17 & 0.17 \\
\hline $\boldsymbol{A}_{\mathbf{1}}$ & 0.611 & 0.833 & 0.667 & 1.000 & 0.733 & 1.000 & 0.444 & 0.238 & 0.749 & 1.000 & 0.333 & 0.667 \\
\hline $\boldsymbol{A}_{\mathbf{2}}$ & 0.556 & 0.778 & 0.467 & 0.867 & 0.564 & 0.818 & 0.365 & 0.079 & 0.547 & 0.798 & 0.333 & 0.667 \\
\hline $\boldsymbol{A}_{\mathbf{3}}$ & 0.778 & 1.000 & 0.333 & 0.600 & 0.433 & 0.547 & 0.333 & 0.159 & 0.389 & 0.596 & 0.333 & 1.000 \\
\hline $\boldsymbol{A}_{\mathbf{4}}$ & 0.667 & 0.889 & 0.067 & 0.267 & 0.093 & 0.384 & 0.762 & 0.000 & 0.049 & 0.266 & 0.333 & 0.667 \\
\hline $\boldsymbol{A}_{\mathbf{5}}$ & 0.333 & 0.556 & 0.133 & 0.600 & 0.138 & 0.593 & 0.841 & 0.270 & 0.059 & 0.601 & 0.333 & 0.667 \\
\hline
\end{tabular}




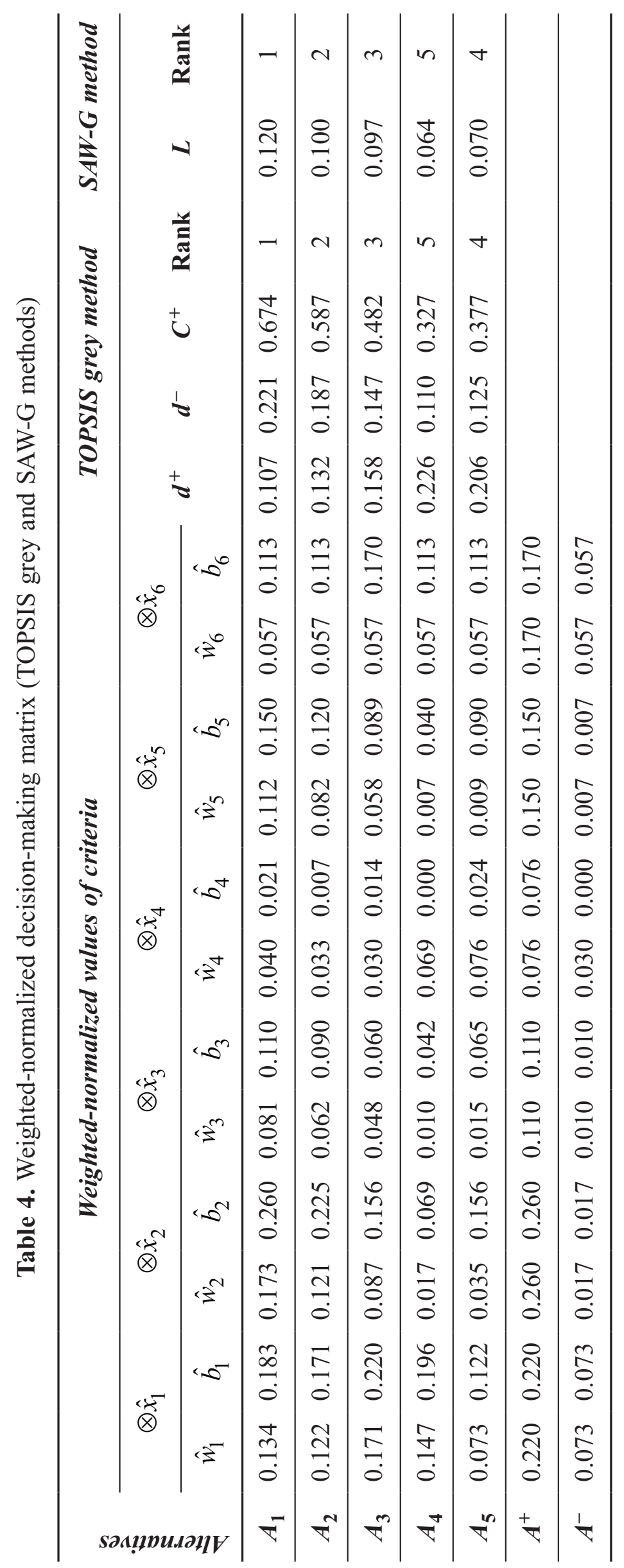


According to the TOPSIS grey and SAW-G methods the order of alternatives ranks is the same. The priority order is: $A_{1}>A_{2}>A_{3}>A_{5}>A_{4}$. The first alternative contractor must be selected as best performing contractor.

\section{Conclusions}

In competitive and risky environment the selection of contractors must be performed according to multiple criteria. In actual multicriteria modelling of multi-alternative problems, values of criteria referring to the future can be expressed at intervals.

The results of the study showed that the newly developed methods TOPSIS grey, SAWG could be successfully applied for the assessment of alternatives described by multiple criteria with values expressed at intervals. This approach is intended to support decision- making process and to increase its efficiency.

\section{References}

Arslan, G.; Kivrak, S.; Birgonul, M. T.; Dikmen, I. 2008. Improving sub-contractor selection process in construction projects: Web-based sub-contractor evaluation system (WEBSES), Automation in Construction 17: 480-488. doi:10.1016/j.autcon.2007.08.004

Bageis, A. S.; Fortune, C. 2009. Factors affecting the bid/no bid decision in the Saudi Arabian construction contractors, Construction Management and Economics 27(1): 53-71. doi:10.1080/01446190802596220

Banaitienė, N.; Banaitis, A.; Kaklauskas, A.; Zavadskas, E. K. 2008. Evaluating the life cycle of building: A multivariant and multiple criteria approach, OMEGA - The International Journal of Management Science 36(3): 429-441. doi:10.1016/j.omega.2005.10.010

Bayraktar, M. E.; Hastak, M. 2009. A decision support system for selecting the optimal contracting strategy in highway work zone projects, Automation in Construction 18(6): 834-843. doi:10.1016/j.autcon.2009.03.007

Boran, F. E.; Genc, S.; Kurt, M.; Akay, D. 2009. A multi-criteria intuitionistic fuzzy group decision making for supplier selection with TOPSIS method, Expert Systems with Applications 36(8): 11363-11368. doi:10.1016/j.eswa.2009.03.039

Brauers, W. K. M.; Zavadskas, E. K.; Peldschus, F.; Turskis, Z. 2008a. Multi-objective decisionmaking for road design, Transport 23(3): 183-193. doi:10.3846/1648-4142.2008.23.183-193

Brauers, W. K. M.; Zavadskas, E. K.; Turskis, Z.; Vilutiene, T. 2008b. Multi-objective contractors' ranking by applying the MOORA method, Journal of Business Economics and Management 9(4): 245-255. doi:10.3846/1611-1699.2008.9.245-255

Bregar, A.; Györkös, J.; Jurič, M. B. 2008. Interactive aggregation/disaggregation dichotomic sorting procedure for group decision analysis based on the threshold model, Informatica 19(2): 161-190.

Buyukozkan, G.; Feyzioglu, O.; Nebol, E. 2008. Selection of the strategic alliance partner in logistics value chain, International Journal of Production Economics 113(1): 148-158.

doi:10.1016/j.ijpe.2007.01.016

Cakir, O. 2008. The grey extent analysis, Kybernetes 37(7): 997-1015.

doi:10.1108/03684920810884379

Cempel, C. 2008. Decomposition of the symptom observation matrix and grey forecasting in vibration condition monitoring of machines, International Journal of Applied Mathematics and Computer Science 18(4): 569-579. doi:10.2478/v10006-008-0050-7 
Chamodrakas, I.; Alexopoulou, N.; Martakos, D. 2009. Customer evaluation for order acceptance using a novel class of fuzzy methods based on TOPSIS, Expert Systems with Applications 36(4): 7409-7415. doi:10.1016/j.eswa.2008.09.050

Chan, E. H. W.; Au, M. C. Y. 2009. Factors influencing building contractors' pricing for timerelated risks in tenders, Journal of Construction Engineering and Management - ASCE: 135(3): 135-145. doi:10.1061/(ASCE)0733-9364(2009)135:3(135)

Chou, S.-Y.; Chang, Y.-H.; Shen, C.-Y. 2008. A fuzzy simple additive weighting system under group decision-making for facility location selection with objective/subjective attributes, European Journal of Operational Research 189(1, 16): 132-145.

Darvish, M.; Yasaei, M.; Saeedi, A. 2009. Application of the graph theory and matrix methods to contractor ranking, International Journal of Project Management 27(6): 610-619.

doi:10.1016/j.ijproman.2008.10.004

Deng, J. L. 1982. Control problems of grey system, Systems and Control Letters 1(5): 288-294. doi:10.1016/S0167-6911(82)80025-X

Deng, J. L. 1988. Introduction to grey system theory, The Journal of Grey Theory 1(1): 1-24.

Deng, J. L. 1989. Properties of relational space for grey systems, in Essential Topics on Grey System - Theory and Applications. China Ocean, 1-13.

Dikmen, I.; Birgonul, M. T.; Anac, C.; Tah, J. H. M.; Aouad, G. 2008. Learning from risks: A tool for post-project risk assessment, Automation in Construction 18(1): 42-50.

doi:10.1016/j.autcon.2008.04.008

Du, J. C.; Shen, D. H. 2005. Development of pavement permanent deformation prediction model by grey modelling method, Civil Engineering and Environmental Systems 22(2): 109-121. doi:10.1080/10286600500126348

Ehrgott, M. 2005. Multicriteria Optimization. Springer.

El-Adaway, I. H.; Kandil, A. A. 2009. Contractors' claims insurance: A risk retention approach, Journal of Construction Engineering and Management - ASCE 135 (9): 819-825.

doi:10.1061/(ASCE)CO.1943-7862.0000033

Enshassi, A.; Choudhry, R. M.; El-Ghandour, S. 2009. Contractors' perception towards causes of claims in construction projects, International Journal of Construction Management 9(1): 79-92. doi:10.1080/01446199100000008

Figueira, J.; Greco, S.; Ehrgott, M. (Eds.). 2005. Multiple Criteria Decision Analysis: State of the Art Surveys. Springer, Berlin.

Ginevičius, R.; Podvezko, V.; Bruzgè, Š. 2008a. Evaluating the effect of state aid to business by multicriteria methods, Journal of Business Economics and Management 9(3): 167-180. doi:10.3846/1611-1699.2008.9.167-180

Ginevicius, R.; Podvezko, V.; Raslanas, S. 2008b. Evaluating the alternative solutions of wall insulation by multicriteria methods, Journal of Civil Engineering and Management 14(4): 217-226. doi:10.3846/1392-3730.2008.14.20

Grassi, A.; Gamberini, R.; Mora, C.; Rimini, B. 2009. A fuzzy multi-attribute model for risk evaluation in workplaces, Safety Science 47(5): 707-716. doi:10.1016/j.ssci.2008.10.002

Han, S. H.; Kim, D. Y.; Kim, H.; Jang, W.-S. 2008. A web-based integrated system for international project risk management, Automation in Construction 17(3): 342-356.

doi:10.1016/j.autcon.2007.05.012

Hartmann, A.; Ling, F. Y. Y.; Tan, J. S. H. 2009. Relative importance of subcontractor selection criteria: Evidence from Singapore, Journal of Construction Engineering and Management ASCE: 135 (9): 826-832. doi:10.1061/(ASCE)0733-9364(2009)135:9(826) 
Huang, J.; Jiang, X.; Tang, Q. 2009. An e-commerce performance assessment model: Its development and an initial test on e-commerce applications in the retail sector of China, Information \& Management 46(2): 100-108. doi:10.1016/j.im.2008.12.003

Huang, Y.-L. 2009. Prediction of contractor default probability using structural models of credit risk: An empirical investigation, Construction Management and Economics 27(6): 581-596. doi:10.1080/01446190902960474

Huang, K. Y.; Jane, C. J. 2009. A hybrid model for stock market forecasting and portfolio selection based on ARX, grey system and RS theories, Expert Systems with Applications 36(3): 5387-5392. doi:10.1016/j.eswa.2008.06.103

Hui, E. C. M.; Lau, O. M. F.; Lo, K. K. 2009. A fuzzy decision-making approach for portfolio management with direct real estate investment, International Journal of Strategic Property Management 13(2): 191-204. doi:10.3846/1648-715X.2009.13.191-204

Hwang, C. L.; Yoon, K. S. 1981. Multiple Attribute Decision Making, Methods and Applications. Springer-Verlag. Berlin, Heidelberg, New York.

Jakimavicius, M.; Burinskiene, M. 2009. GIS and multi-criteria-based analysis and ranking of transportation zones of Vilnius city, Technological and Economic Development of Economy 15(1): 39-48. doi:10.3846/1392-8619.2009.15.39-48

Jakimavicius, M.; Burinskiene, M. 2009. Assessment of Vilnius city development scenarios based on transport system modelling and multicriteria analysis, Journal of Civil Engineering and Management 15(4): 361-368. doi:10.3846/1392-3730.2009.15.361-368

Jurkštienè, A.; Darškuvienè, V.; Dūda, A. 2008. Management control systems and stakeholders' interests in Lithuanian multinational companies: cases from the telecommunications industry, Journal of Business Economics and Management 9(2): 97-106.

doi:10.3846/1611-1699.2008.9.97-106

Kalibatas, D.; Turskis, Z. 2008. Multicriteria evaluation of inner climate by using MOORA method, Information Technology and Control 37(1): 79-83.

Kapliński, O. 2008. Usefulness and credibility of scoring methods in construction industry, Journal of Civil Engineering and Management 14(1): 21-28. doi:10.3846/1392-3730.2008.14.21-28

Karnitis, E.; Kucinskis, M. 2009. Strategic planning and management of national development processes in Latvia, Journal of Business Economics and Management 10(1): 3-13. doi:10.3846/1611-1699.2009.10.3-13

Kendall, M. G. 1970. Rank correlation methods. 4th ed. London Griffin.

Kuo, Y.; Yang, T.; Huang, G.-W. 2008. The use of grey relational analysis in solving multiple attribute decision-making problems, Computers \& Industrial Engineering 55(1): 80-93. doi:10.1016/j.cie.2007.12.002

Lam, K.-C.; Ning, X.; Gao, H. 2009. The fuzzy GA-based multi-objective financial decision support model for Chinese state-owned construction firms, Automation in Construction 18(4): 402-414. doi:10.1016/j.autcon.2008.10.004

Leephakpreeda, T. 2008. Grey prediction on indoor comfort temperature for HVAC systems, Expert Systems with Applications 34(4): 2284-2289. doi:10.1016/j.eswa.2007.03.003

Li, G. D.; Yamaguchi, D.; Nagai, M. 2008. A grey-based rough decision-making approach to supplier selection, International Journal of Advanced Manufacturing Technology 36(9-10): 1032-1040. doi:10.1007/s00170-006-0910-y

Li, Q.-X.; Liu, S.-F. 2009a. The grey input-occupancy-output analysis, Kybernetes: The International Journal of Systems \& Cybernetics 38(3-4): 306-313(8).

Li, Q.-X.; Liu, S.-F. 2009b. Some results about grey mathematics, Kybernetes: The International Journal of Systems \& Cybernetics 38(3-4): 297-305(9). 
Li, Z.; Wang, W.; Chen, M.-y. 2009. Improved grey-Markov chain algorithm for forecasting, Kybernetes 38(3/4): 329-338. doi:10.1108/03684920910944010

Liaudanskiene, R.; Ustinovicius, L.; Bogdanovicius, A. 2009. Evaluation of construction process safety solutions using the TOPSIS method, Inzinerine Ekonomika - Engineering Economics (4): $32-40$.

Lin, Y.-H.; Lee, P.-C. 2007. Novel high-precision grey forecasting model, Automation in Construction 16(6): 771-777. doi:10.1016/j.autcon.2007.02.004

Lin, Y.; Chen, M.-Y.; Liu, S. 2004. Theory of grey systems: capturing uncertainties of grey information, Kybernetes 33(2): 196-218. doi:10.1108/03684920410514139

Lin, Y.-H.; Lee, P.-C.; Chang, T.-P.; Ting, H.-I. 2008. Multi-attribute group decision making model under the condition of uncertain information, Automation in Construction 17(6): 792-797. doi:10.1016/j.autcon.2008.02.011

Liu, S.; Lin, Y. 2006. On measures of information content of grey numbers, Kybernetes 35(6): 899-904. doi:10.1108/03684920610662692

Liu, S. F.; Forrest, J.; Vallee, R. 2009. Emergence and development of grey systems theory, Kybernetes 38(7-8): 1246-1256. doi:10.1108/03684920910976943

MacCrimon, K. R. 1968. Decision making among multiple attribute alternatives: A survey and consolidated approach, Rand Memorandum, RM-4823-ARPA.

Mitkus, S.; Šstak, O. R. 2008. Modelling the process for defence of third party rights infringed while implementing construction investment projects, Technological and Economic Development of Economy 14(2): 208-223. doi:10.3846/1392-8619.2008.14.208-223

Mitkus, S.; Trinkuniene, E. 2008. Reasoned decisions in construction contracts evaluation, Technological and Economic Development of Economy 14(3): 402-416.

doi:10.3846/1392-8619.2008.14.402-416

Opricovic, S. 1998. Multicriteria optimization of civil engineering systems. Faculty of Civil Engineering, Belgrade (in Serbian).

Opricovic, S.; Tzeng, G.-H. 2004. Compromise solution by MCDM methods: A comparative analysis of VIKOR and TOPSIS, European Journal of Operational Research 156: 445-455. doi:10.1016/S0377-2217(03)00020-1

Padhi, S. S.; Mohapatra, P. K. J. 2009. Contractor selection in government procurement auctions: A case study, European Journal of Industrial Engineering 3(2): 170-186. doi:10.1504/EJIE.2009.023604

Plebankiewicz, E. 2009. Contractor prequalification model using fuzzy sets, Journal of Civil Engineering and Management 15(4): 377-385. doi:10.3846/1392-3730.2009.15.377-385

Reichelt, B.; Melnikas, B.; Vilutienè, T. 2008. The model for selection of a maintenance strategy for municipal buildings. International Journal of Environment and Pollution 35(2-4): 219-236. doi:10.1504/IJEP.2008.021357

Schieg, M. 2008. Strategies for avoiding asymmetric information in construction project management, Journal of Business Economics and Management 9(1): 47-51.

doi:10.3846/1611-1699.2008.9.47-51

Schieg, M. 2009. Model for integrated project management, Journal of Business Economics and Management 10(2): 149-160. doi:10.3846/1611-1699.2009.10.149-160

Shevchenko, G.; Ustinovichius, L.; Andruškevičius, A. 2008. Multi-attribute analysis of investments risk alternatives in construction, Technological and Economic Development of Economy 14(3): 428-443. doi:10.3846/1392-8619.2008.14.428-443

Šiškina, A.; Juodis, A.; Apanavičiene, R. 2009. Evaluation of the competitiveness of construction company overhead costs, Journal of Civil Engineering and Management 15(2): 215-224. doi:10.3846/1392-3730.2009.15.215-224 
Smyth, H.; Fitch, T. 2009. Application of relationship marketing and management: A large contractor case study, Construction Management and Economics 27(4): 399-410.

doi:10.1080/01446190902777365

Stasiškienè, Ž.; Šliogerienè, J. 2009. Sustainability assessment for corporate management of energy production and supply companies for Lithuania, International Journal of Strategic Property Management 13(1): 71-81. doi:10.3846/1648-715X.2009.13.71-81

Straub, A. 2009. Cost savings from performance-based maintenance contracting, International Journal of Strategic Property Management 13(3): 205-217.

doi:10.3846/1648-715X.2009.13.205-217

Suhobokov, A. 2007. Application of Monte Carlo simulation methods in risk management, Journal of Business Economics and Management 8(3): 165-168.

Tieva, A.; Junnonen, J.-M. 2009. Proactive contracting in Finnish PPP projects, International Journal of Strategic Property Management 13(3): 219-228. doi:10.3846/1648-715X.2009.13.219-228

Turskis, Z. 2008. Multi-attribute contractors ranking method by applying ordering of feasible alternatives of solutions in terms of preferability technique, Technological and Economic Development of Economy 14(2): 224-239. doi:10.3846/1392-8619.2008.14.224-239

Turskis, Z.; Zavadskas, E. K.; Peldschus, F. 2009. Multi-criteria optimization system for decision making in construction design and management, Inzinerine Ekonomika-Engineering Economics 1(61): 7-17.

Tvaronavičienė, M.; Grybaite, V. 2007. Impact of FDI on Lithuanian economy: insight into development of main economic activities, Journal of Business Economics and Management 8(4): 285-290.

Ulubeyli, S.; Kazaz, A. 2009. A multiple criteria decision-making approach to the selection of concrete pumps, Journal of Civil Engineering and Management 15(4): 369-376.

doi:10.3846/1392-3730.2009.15.369-376

Urbanavičienè, V.; Kaklauskas, A.; Zavadskas, E. K. 2009. The conceptual model of construction and real estate negotiation, International Journal of Strategic Property Management 13(1): 53-70. doi:10.3846/1648-715X.2009.13.53-70

Walraven, A.; de Vries, B. 2009. From demand-driven contractor selection towards value-driven contractor selection, Construction Management and Economics 27(6): 597-604.

doi:10.1080/01446190902933356

Wending, H.; Ben, H.; Changzhi, Y. 2002. Building thermal process analysis with grey system method, Building and Environment 37: 599-605. doi:10.1016/S0360-1323(01)00062-2

Yan, J. Y.; Yang, J. G. 2009. Application of synthetic grey correlation theory on thermal point optimization for machine tool thermal error compensation, The International Journal of Advanced Manufacturing Technology 43(11-12): 1124-1132. doi:10.1007/s00170-008-1791-z

Yang, J.; Shen, G. Q.; Ho, M.; Drew, D. S.; Chan, A. P. C. 2009a. Exploring critical success factors for stakeholder management in construction projects, Journal of Civil Engineering and Management 15(4): 337-348. doi:10.3846/1392-3730.2009.15.337-348

Yang, Z. L.; Bonsall, S.; Wang, J. 2009b. Use of hybrid multiple uncertain attribute decision making techniques in safety management, Expert Systems with Applications 36(2) part 1: 1569-1586.

Zanakis, S. H.; Solomon, A.; Wishart, N.; Dublish, S. 1998. Multi-attribute decision making: A simulation comparison of select methods, European Journal of Operational Research 107(3): 507-529. doi:10.1016/S0377-2217(97)00147-1

Zavadskas, E. K.; Kaklauskas, A. 2007. Mehrzielselektion für Entscheidungen im Bauwesen. Fraunhofer IRB Verlag (in German). 
Zavadskas, E. K.; Turskis, Z. 2008. A new logarithmic normalization method in game theory, Informatica 19(2): 303-314.

Zavadskas, E. K.; Vaidogas, E. R. 2008. Bayesian reasoning in managerial decisions on the choice of equipment for the prevention of industrial accidents, Inzinerine Ekonomika - Engineering Economics 5(60): 32-40.

Zavadskas, E. K.; Kaklauskas, A.; Turskis, Z.; Tamošaitienè, J. 2008a. Selection of the effective dwelling house walls by applying attributes values determined at intervals, Journal of Civil Engineering and Management 14(2): 85-93. doi:10.3846/1392-3730.2008.14.3

Zavadskas, E. K.; Liias, R.; Turskis, Z. 2008b. Multi-attribute decision-making methods for assessment of quality in bridges and road construction: State-of-the-art surveys, The Baltic Journal of Road and Bridge Engineering 3(3): 152-160. doi:10.3846/1822-427X.2008.3.152-160

Zavadskas, E. K.; Raslanas, S.; Kaklauskas, A. 2008c. The selection of effective retrofit scenarios for panel houses in urban neighbourhoods based on expected energy savings and increase in market value: The Vilnius case, Energy and Buildings 40(4): 573-587.

doi:10.1016/j.enbuild.2007.04.015

Zavadskas, E. K.; Turskis, Z.; Tamošaitiene, J. 2008d. Contractor selection for construction in a competitive environment, Journal of Business Economics and Management 9(3): 181-187. doi:10.3846/1611-1699.2008.9.181-187

Zavadskas, E. K.; Turskis, Z.; Tamošaitienè, J.; Marina, V. 2008e. Multicriteria selection of project managers by applying grey criteria, Technological and Economic Development of Economy 14(4): 462-477. doi:10.3846/1392-8619.2008.14.462-477

Zavadskas, E. K.; Kaklauskas, A.; Turskis, Z; Tamosaitiene, J. 2009. Multi-attribute decisionmaking model by applying grey numbers, Informatica 20(2): 305-320.

Zeydan, M.; Colpan, C. 2009. A new decision support system for performance measurement using combined fuzzy TOPSIS/DEA approach, International Journal of Production Research 47(15): 4327-4349. doi:10.1080/00207540802662870

\section{RANGOVU PARINKIMAS STATYBOS DARBAMS ATLIKTI TAIKANT SAW-G IR TOPSIS GREY SKAIČIŲ TECHNOLOGIJAS}

\section{E. K. Zavadskas, T. Vilutienė, Z. Turskis, J. Tamošaitienė}

Santrauka

Taikant daugiatikslius metodus įprastai rodiklių reikšmės imamos kaip tikslios. Pilkujų skaičių teorija yra naujas metodas, kuri galima taikyti daugelyje sričių: tinkamumui numatyti, nagrinėti santykius ir priimti sprendimus. Šiame straipsnyje pateiktas pilkujų skaičių teorijos taikymo pavyzdys alternatyvų tikslingumui nustatyti. Pasiūlytas metodas apima gerai žinomą TOPSIS (pirmumo eilès nustatymo būdas pagal našumą ir idealų sprendini) metodą su rodiklių reikšmèmis, apibrežtomis intervaluose (TOPSIS-grey) ir paprastojo suminio svèrimo su pilkaisiais santykiais (SAW-G) metodą. Rangovų kompetencijos vertinimo pavyzdys pateiktas naujo metodo efektyvumui parodyti. Uždavinio sprendimas parodo, kad uždavinių modeliai, aprašyti pilkaisiais santykiais, gali būti efektyviai taikomi uždaviniams su neapibrèžtais duomenimis spręsti.

Reikšminiai žodžiai: rangovai, statyba, daugiatikslis sprendimu prièmimas, pilkieji skaičiai, SAW, SAW-G, TOPSIS, TOPSIS grey. 
Edmundas Kazimieras ZAVADSKAS is a principal vice-rector of Vilnius Gediminas Technical University and Head of the Dept. of Construction Technology and Management at Vilnius Gediminas Technical University, Vilnius, Lithuania. He has a PhD in building structures (1973) and Dr Sc (1987) in building technology and management. Member of Lithuanian and several foreign Academies of Sciences and Doctor honoris causa at Poznan, Saint-Petersburg, and Kiev Universities. Also, a member of international organisations and a member of steering and programme committees at many international conferences. E. K. Zavadskas is a member of editorial boards of several research journals as well as the author and co-author of more than 300 papers and a number of monographs in Lithuanian, English, German and Russian. Research interests: building technology and management, decision-making theory, automated design and decision support systems.

Tatjana VILUTIENE. Doctor, Assoc. Prof. in the Dept. of Construction Technology and Management at Vilnius Gediminas Technical University, Vilnius, Lithuania. She is the coordinator of EURO Working Group „OR in Sustainable Development and Civil Engineering“. She is and has been a member of organizing committees at international conferences. She is the author of 1 textbook for students published in Lithuanian and about 20 scientific papers. Her research interests include decision-making in construction, project management in construction, facilities management, and quality management.

Zenonas TURSKIS. PhD, a senior research fellow in Construction Technology and Management Laboratory of Vilnius Gediminas Technical University, Lithuania. His research interests include building technology and management, decision-making theory, computer-aided design and expert systems. Author of 20 research papers.

Jolanta TAMOŠAITIENĖ. Doctor, Dean assistant of Civil Engineering Faculty, Vilnius Gediminas Technical University, reader lecturer of the Dept. of Construction Technology and Management, Vilnius Gediminas Technical University, Lithuania. BSc degree (building technology and management), Vilnius Gediminas Technical University (2000). MSc degree (Building management and economics), Vilnius Gediminas Technical University (2002). She is the member of EURO Working Group „OR in Sustainable Development and Civil Engineering“. She has published 9 scientific papers. Research interests: construction technology and organisation, construction project administration, decision-making and grey theory. 